\title{
Growth, Fruit Yield and Quality of Three Strawberry Cultivars as Affected by Mulch Type and Low Tunnel
}

\author{
Mohamed A. Soliman ${ }^{1}$, Hala A. Abd El-Aal ${ }^{2}$, Ramadan, A. Mohmed ${ }^{1}$ and Nabil N. Elhefnawy ${ }^{2}$
}

\begin{abstract}
Two field experiments were carried out to study the effects of three mulch treatments (black polyethylene, clear polyethylene in addition to a non-mulched control) under low tunnel system (with and without tunnel), on plant growth, flowering traits, fruit yield and quality of three strawberry cultivars (Fragaria \& ananassa Duch); Festival, Sweet Charlie and Gaviota, grown in sandy soil under a drip irrigation system. The results indicated that the three tested strawberry cultivars which were mulched with clear or black polyethylene and tunneled exhibited significant increases in number of leaves, number of crown, leaf area, dry mass/plant, number of flower trusses / plant and it flowered earlier than the non-mulched and non- tunneled ones. Moreover, most yield potential characters i.e. early yield, total yield, yield/plant, marketable yield, culls yield and average fruit weight; were positively and significantly increased by the application of mulch (clear and black polyethylene mulch) and tunneled compared to non-mulched and non-tunneled ones. Furthermore, these treatments, significantly, enhanced most fruit quality characteristics; total soluble solids, total titratable acidity, ascorbic acid, and reducing, non-reducing and total sugars compared to the control. Both Festival and Sweet Charlie cultivars were exceeded Gaviota one, in this respect.
\end{abstract}

Key words: Strawberry Cultivars, Polyethylene Plastic Mulch, Low Tunnels

\section{INTRODUCTION}

Strawberry (Fragaria \& ananassa Duch) is one of the most popular vegetable crops. In Egypt, it occupies an important position among the non-traditional vegetable crops due to its multifarious use for local fresh consumption, exportation and food processing. Potentially, it is one of the most profitable horticultural Egyptian exports to Europe (El-Shall et al 2003). In recent years, there have been interests to study bioactive compounds of strawberries with an impact on human health such as ascorbic and ellagic acids (Wang et al 2002). Strawberries are rich in total antioxidents and are thus important for human health (Halvorsen et al 2002). However, the quality and quantity of these compounds are affected by genetic, environmental and agricultural factors (Kallio et al 2000; Anttonen and Karjalianen, 2005).

Mulch is any material used to cover the surface of the garden soil. There are many types of mulching materials, but they can be divided into two general categories; natural and synthetic. Synthetic-mulches are plastic and papers. The crops vary in their response to polyethylene mulch covers depending on cultivar, materials used, color and environmental conditions (Salman et al 1991; Pan et al 1999). Many researchers pointed that mulching had clear effects on microclimate around the plants by modifying the radiation budget of the surface and give significant increased on vegetative growth of many vegetable (Aguyoh and taber, 1999; Osiru and Hahn, 1994). Growing day-neutral strawberry using plastic mulch stimulate growth of young plants, increase soil temperature, weed control, reduces evapotranspiration, maximize water use efficiency and restrains heat loss during cold nights (Lieten, 1991; Gimenez et al 2002). Furthermore, it improves the protability by increasing the productivity and/or early fruit production as well as enhancing fruit quality (Orzolek and Murphy, 1993). Positive significant effects of organic and synthetic mulches on vegetative growth, flowering traits and yield and its components of strawberry plants have been reported by several investigators (Kher et al 2010; Hasanein et al 2011; Medina et al 2011; Li-fan et al 2012; Abou Elyazied and Mady, 2012; Muhammad Haroon et al 2014). Plants mulched with straw or white-on-black polyethylene flowered and yielded more than plants mulched with clear or white polyethylene. Conversely, more crown and root dry weight (DW) were associated with straw or clear-on-black polyethylene, (Fear and Nonnecke, 1989). Black polyethylene provides higher soil temperature in spring than hairy vetch mulch (Teasdale and Abdul-Baki, 1995; Teasdale and AbdulBaki, 1997). Abou Elyazied and Mady, (2012) found that plastic mulch, significantly, increased NPK content and reduced the number of days to first flower, number flower/cluster and increase the final yield of strawberry plants than control.

Fruit quality of strawberry plants was affected by many factors including cultivar, mulching system, fertilization, irrigation and temperature (Khanizadeh, 1994; Kivijarvi et al., 2002; Anttonen et al., 2006). Nestby et al., (1985) demonstrated that the use of color polyethylene mulch had increased the percentage total soluble solids (Brix), vitamin C content, phenolic, total

${ }^{1}$ Horticulture Research Institute - Agricultural Research Center.

${ }^{2}$ Environmental studies and Research Institute - University of Sadat City

Received October 18, 2015, Accepted December 28, 2015 
anthocyanin and ellagic acid of strawberry plants compared with the control.

High and low tunnels are very common in the Mediterranean regions and Asia (Faspi et al., 2006) as they prolong the harvesting period and improve fruit quality. A high tunnel fruit growing system provides a competitive edge in the market, compared with a field growing system (Kadir et al., 2006). Significant, effects of high tunnels on vegetative growth, flowering traits, yield and fruit quality of strawberry plants were reported by Qureshi et al., (2012).

The objective of the present study was to compare the effects of two types of mulch (black polyethylene, clear polyethylene in addition to a non-mulched control) under low tunnel system (with and without) for three strawberry cultivars; Sweet Charlie, Gaviota, Festival on vegetative growth, flowering traits, fruit yield and quality and chemical composition.

\section{MATERIALS AND METHODS}

\section{Strawberry cultivars}

Three cultivars of strawberry widely cultivated in Egypt were chosen. These cultivars represent the most sugary with excellent flavor; c.v Sweet Charlie and the universally grown, high yielding and good quality; c.vs, Gaviota and festival. Frigo transplants of the tested strawberry cultivars were obtained from Strawberry and Non-Traditional Crops Research Station Nobaria, ElBuhiera Governorate, Egypt. The transplanting date into the field were on September 1 and 25, in the first and second growing seasons, respectively.

\section{Experimental procedure}

Two field experiments were conducted during the growing seasons of 2012/2013 and 2013/2014 at the Experimental Station Farm Horticultural Research Institute (South Tahrir), El-Buhiera Governorate, under drip irrigation system. Some physical and chemical properties of the two experimental sites were determined according to methods described by Black, (1965) and presented in Table (1). The experimental layout was a split-split plot system in a randomized complete blocks design with four replications. Strawberry cultivars were arranged as the main plots and the plastic mulches treatments were considered as the sub - plots; while, the low tunnels systems were placed in the sub-sub-plots. Each sub-sub-plot was two rows of $2.40 \mathrm{~m}$ width and $3 \mathrm{~m}$ length having an area 7.2 $\mathrm{m}^{2}$.A drip irrigation network was designed for this study. The drip irrigation network consisted of lateral's GR of $16 \mathrm{~mm}$ in diameter, with emitters at $0.5 \mathrm{~m}$ distance, with allocating two laterals for each ridge. The emitters had a discharge rate $41 \mathrm{~h}^{-1}$.

All Agricultural practices such as fertigation and disease and pest control were carried out whenever it was necessary according to the recommendations of the commercial production of strawberry commercial production as outlined by Ministry of Agriculture. During the entire growing season, nitrogen, potassium and phosphor fertilizers were also added through the drip irrigation system four times per week, at the rates of $200 \mathrm{~kg} \mathrm{~N} / \mathrm{fed}$, in the form of ammonium nitrate $(20.5 \% \mathrm{~N}), 120 \mathrm{~kg} \mathrm{~K} \mathrm{~K}_{2} \mathrm{O} / \mathrm{fed}$. as soluble potassium sulphate $\left(\begin{array}{lll}48 \% & \mathrm{k}_{2} \mathrm{O}\end{array}\right)$ and $80 \mathrm{~kg} \quad \mathrm{P}_{2} \mathrm{O}_{5} /$ fed as soluble phosphoric acid.

\section{Data Recorded}

\section{1- Vegetative growth traits}

At full blooming stage, Five representative plant sample were randomly chosen from each sub-sub plot to measurement the number of crowns/ plant, the number of leaves/ plant, plant leaf area $\left(\mathrm{cm}^{2}\right)$ and plant dry mass (g) were recorded.

\section{2- Yield potential}

Early fruit yield was calculated in ton/ fed. as the fresh weight of harvested fruits from the first four pickings. Total yield was calculated in ton /fed. as the fresh weight of all harvested fruits throughout the growing season. Yield /plant (g) was calculated in a random sample of ten plants per sub-sub plot at each picking.

\section{3-Yield components}

Average fruit weight $(\mathrm{g})$, was calculated in a random sample of ten plants per sub-sub plot at each harvest. Non-marketable yield (ton/fed), including splitter, malformed, green shouldered, white tip, damaged and rotted fruits was determined at each picking. Marketable yield (ton/fed) was calculated at each picking.

\section{Table 1. Some physical and chemical analyses of the experimental sites of the 2012/2013 and} 2013/2014 growing season

\begin{tabular}{|c|c|c|c|c|c|c|c|c|c|c|c|}
\hline \multirow{3}{*}{ 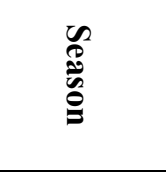 } & \multicolumn{3}{|c|}{ Physical characteristics } & \multicolumn{8}{|c|}{ Chemical characteristics } \\
\hline & \multirow{2}{*}{ Sand $\%$} & \multirow{2}{*}{ Silt $\%$} & \multirow{2}{*}{ Clay $\%$} & \multirow{2}{*}{$\begin{array}{c}\mathrm{EC} \\
\mathrm{ds} / \mathrm{m}\end{array}$} & \multirow[t]{2}{*}{$\mathbf{P H}$} & \multicolumn{3}{|c|}{$\begin{array}{c}\text { Soluble cations } \\
\mathrm{mg} / \mathbf{l}\end{array}$} & \multicolumn{2}{|c|}{$\begin{array}{c}\text { Soluble anions } \\
\mathrm{mg} / \mathrm{l}\end{array}$} & \multirow[t]{2}{*}{ Total N } \\
\hline & & & & & & $\mathbf{C a}$ & mg & $\mathbf{K}$ & $\mathrm{HCO}_{3}$ & $\mathrm{So}_{4}$ & \\
\hline $2012 / 2013$ & 93 & 5 & 2 & 0.16 & 8.9 & 0.72 & 0.54 & 0.23 & 0.59 & 0.54 & 0.007 \\
\hline $2013 / 2014$ & 94 & 4 & 2 & 0.21 & 8.8 & 0.69 & 0.55 & 0.20 & 0.56 & 0.55 & 0.009 \\
\hline
\end{tabular}




\section{4- Fruit quality}

Random samples of ten fruits were taken from each sub-sub plot at monthly intervals starting from the first harvest, to determine fruit characteristics. Moisture content (\%): was determined on fresh weight basis by calculating the difference between fruit fresh weight and oven dried $\left(70{ }^{\circ} \mathrm{C}\right.$ until a constant weight) fruits/fruit fresh weight $\times 100$. Total soluble solids (TSS $\%$ ): was determined using a carlzeiss hand refractometer.

Reducing and total sugars: were determined according to Nelson's method as illustrated by Mailk and Singh, (1980). Means while the non-reducing sugars were calculated by the difference between total and reducing sugars.

\section{Statistical analysis:}

The obtained data were statically analyzed using Statistical Analysis System (SAS), version 6(SAS INSTITUTE INC, Cary, USA).Differences between means were compared by Revised the Least Significant Difference test (LSD) at 0.05 levels.

\section{RESULTS AND DISCUSSION}

\section{1- Vegetative growth traits:}

Results in Table (2) indicated that Festival cultivar recorded the highest mean values for most vegetative growth parameters i.e. number of leaves and crowns, dry mass and leaf area compared with those of Sweet Charlie and Gavuta, in both seasons. The obtained results seemed to complement with those reported by Shiow et al (1998). The results presented in Table (2), generally, clarified the presence of some significant increments on all studied vegetative growth characters of strawberry plant as a result of application of mulches type and tunnels compared with control (non-mulched / non-tunneled), in both seasons. The black polyethylene mulch recorded the highest mean values for all studied growth characters, in both seasons. The lowest mean values of vegetative growth characters were obtained by no soil cover (non-mulched control) treatment. The detected pronounced positive effect of mulches type on the vegetative parameters might be due to the reduced soil erosion; weed emergence; water loss; increased nitrogen; recycling of nutrients and addition of organic matter to the soil. These results, generally, are matched with those reported by Himelrick, (1982); Blatt, (1984); Nestby, (1985) and Fear Nonneck, (1989). Executing the low tunnel resulted in higher vegetative growth than the non-tunneled control. The benefits of plastic tunnels lead to maximum water use efficiency by the plant and reduce weeds which positively reflect on vegetative growth characters (Gimenez et al 2002).
The results in Table (3) illustrated the interaction effect between (cultivars $\times$ mulch types) on vegetative growth characters of strawberry plants. In both season, significant difference were detected in all vegetative growth traits as a result of the combination between the different mulches and cultivars. The best treatment combination for most vegetative growth characters was obtained when the strawberry plants cv Festival were mulched by black polyethylene, in both seasons.

The interaction effect between tunnel and cultivar on vegetative growth traits are presented in Table(4). Strawberry cv. Festival or Sweet Charlie under low tunnel was responsible for the significant increments for all studied vegetative growth traits, in both seasons. Similar results were reported by Qureshi et al., (2012).

The obtained results presented in Table (5) reflected the significant interaction effects between (mulches type $\times$ tunnel) on vegetative growth characters of strawberry plants. Application of mulch treatments either black or clear under the low tunnel, significantly, produced more vegetative growth traits, in both seasons. Black mulch exhibited higher mean values for all vegetative growth traits in tunnels, in both seasons. The obtained results seemed to complement with those reported by Medin et al., (2011) and Levent and Sozer, (2001).

\section{2- Flowering traits:}

The obtained results tabulated in Table (6) reported that strawberry cvs. Festival and Sweet Charlie were earlier and produced higher number of flower trusses/ plant than Gaviota one. The effect of various mulch types and tunnels on flowering time (earliness) and number of flower trusses / plant were found significant, in both seasons (Table 6). The strawberry plants which were mulched and tunneled flowered earlier and produced more flower trusses than the control (nonmulched and non-tunneled). The observed enhancement effect on flowering parameters due to type of mulches might be attributed to the benefits of organic and synthetic mulches which led to decrease water loss and soil temperature during the hot summer months, reduced soil erosion and action as a slow-release fertilizer (Teasdele and Abdul-backi, 1993). Also, it leads to promote vegetative growth which positively reflects on flowering traits. The low tunnels increased temperature $1-2{ }^{\circ} \mathrm{C}$ and enables the plant growing during critical development period, which reflect on flowering traits (Sevgican, 1984). These results seemed to be in general agreements with those reported by Sevgican (1984); Fear and Nonnecke, (1989) and Levent and Sozer, (2001), who reported that plants mulched with black mulches and tunnels flowered and yielded earlier than control one. 
Table 2. The Main effects of cultivar, mulch and tunnel on vegetative growth characters of strawberry plant, during the seasons of 2012/2013 and 2013/2014.

\begin{tabular}{|c|c|c|c|c|c|c|c|c|}
\hline \multirow[t]{2}{*}{ Treatment } & \multicolumn{2}{|c|}{ Number of leaves } & \multicolumn{2}{|c|}{ Number of crown } & \multicolumn{2}{|c|}{$\begin{array}{c}\text { Total dry weight (g } \\
\text { m) }\end{array}$} & \multicolumn{2}{|c|}{ Leaf area $\left(\mathrm{cm}^{2}\right)$} \\
\hline & Season 1 & Season 2 & Season 1 & Season 2 & Season 1 & Season 2 & Season 1 & Season 2 \\
\hline Cultivar Gafuta & $19.98 \mathrm{~b}$ & $15.13 \mathrm{~b}$ & $3.38 \mathrm{a}$ & $2.84 \mathrm{~b}$ & $6.76 \mathrm{c}$ & $6.43 \mathrm{~b}$ & $237.51 \mathrm{c}$ & $222.95 \mathrm{~b}$ \\
\hline Festival & $25.76 \mathrm{a}$ & $21.65 \mathrm{a}$ & $3.50 \mathrm{a}$ & $3.51 \mathrm{a}$ & $18.30 \mathrm{a}$ & $15.28 \mathrm{a}$ & $640.63 a$ & $621.72 \mathrm{a}$ \\
\hline reet Charlie & $22.31 \mathrm{ab}$ & $20.20 \mathrm{a}$ & $3.98 \mathrm{a}$ & $3.33 \mathrm{a}$ & $12.44 \mathrm{~b}$ & $13.97 \mathrm{a}$ & $430.91 \mathrm{~b}$ & $511.65 \mathrm{a}$ \\
\hline Control & $19.48 \mathrm{~b}$ & $17.12 \mathrm{~b}$ & $2.73 \mathrm{~b}$ & $2.33 \mathrm{~b}$ & $9.15 b$ & $8.21 \mathrm{~b}$ & $343.75 c$ & $345.23 b$ \\
\hline Clear & $23.48 \mathrm{a}$ & $19.42 \mathrm{a}$ & $3.86 \mathrm{a}$ & $3.91 \mathrm{a}$ & $12.67 \mathrm{a}$ & $12.86 \mathrm{a}$ & $426.77 \mathrm{~b}$ & $518.37 \mathrm{a}$ \\
\hline Black & $25.09 \mathrm{a}$ & $20.43 \mathrm{a}$ & $4.27 \mathrm{a}$ & $3.44 \mathrm{a}$ & $15.63 \mathrm{a}$ & $14.63 \mathrm{a}$ & $538.50 \mathrm{a}$ & $492.72 \mathrm{a}$ \\
\hline Tunnel & $21.77 \mathrm{a}$ & $17.24 \mathrm{~b}$ & $3.54 \mathrm{a}$ & $2.55 \mathrm{~b}$ & $11.62 \mathrm{a}$ & $11.39 \mathrm{a}$ & $418.99 \mathrm{~b}$ & $440.66 a$ \\
\hline Tunnel & $23.59 \mathrm{a}$ & $20.75 \mathrm{a}$ & $3.70 \mathrm{a}$ & $3.91 \mathrm{a}$ & $13.34 \mathrm{a}$ & $12.40 \mathrm{a}$ & $453.69 \mathrm{a}$ & $463.55 \mathrm{a}$ \\
\hline
\end{tabular}

Values followed by the same letter(s), within a comparable group of means of any main effect, do not significantly differ, using revised L.S.D test at $0.05 \%$ level

Table 3. The Interaction effect between cultivar and mulch on vegetative growth characters of strawberry plants, during the seasons of 2012/2013 and 2013/2014.

\begin{tabular}{|c|c|c|c|c|c|c|c|c|c|}
\hline \multirow[t]{3}{*}{ Cultivar } & \multirow{3}{*}{ Mulch } & \multicolumn{2}{|c|}{ Number of leaves } & \multicolumn{2}{|c|}{ Number of crown } & \multicolumn{2}{|c|}{$\begin{array}{l}\text { Total dry weight } \\
\text { (g m) }\end{array}$} & \multicolumn{2}{|c|}{$\begin{array}{c}\text { Leaf area } \\
\left(\mathrm{cm}^{2}\right)\end{array}$} \\
\hline & & Season & Season & Season & Season & Season & Season & Season & Season \\
\hline & & 1 & 2 & 1 & 2 & 1 & 2 & 1 & 2 \\
\hline \multirow[t]{3}{*}{ Gafuta } & Un- mulched & $18.91 \mathrm{c}$ & $10.03 \mathrm{c}$ & $2.92 \mathrm{~d}$ & $1.75 \mathrm{~d}$ & $5.78 \mathrm{~d}$ & $5.49 \mathrm{~d}$ & $219.18 \mathrm{c}$ & $201.64 \mathrm{~b}$ \\
\hline & clear mulch & $22.38 \mathrm{bc}$ & $17.94 \mathrm{~b}$ & $3.52 \mathrm{~cd}$ & $3.97 \mathrm{a}$ & $8.19 \mathrm{~d}$ & $7.81 \mathrm{~d}$ & $288.78 \mathrm{bc}$ & $267.95 \mathrm{~b}$ \\
\hline & Black mulch & $18.66 \mathrm{c}$ & $17.42 \mathrm{~b}$ & $3.71 \mathrm{bcd}$ & $2.80 \mathrm{bc}$ & $6.303 \mathrm{~d}$ & $6.01 \mathrm{~d}$ & $204.53 \mathrm{c}$ & $199.25 \mathrm{~b}$ \\
\hline \multirow[t]{3}{*}{ Festival } & Un -mulched & $21.17 \mathrm{c}$ & $22.66 \mathrm{a}$ & $1.89 \mathrm{e}$ & $2.72 \mathrm{bc}$ & $14.22 \mathrm{bc}$ & $12.52 \mathrm{c}$ & $604.49 \mathrm{a}$ & $554.34 \mathrm{a}$ \\
\hline & clear mulch & $27.62 \mathrm{ab}$ & $20.11 \mathrm{ab}$ & $3.95 \mathrm{abc}$ & $4.27 \mathrm{a}$ & $19.51 \mathrm{ab}$ & $18.01 \mathrm{~b}$ & $622.41 \mathrm{a}$ & $685.57 \mathrm{a}$ \\
\hline & Black mulch & $28.49 \mathrm{a}$ & $22.16 \mathrm{a}$ & $4.65 \mathrm{a}$ & $3.50 \mathrm{ab}$ & $21.04 \mathrm{a}$ & $15.32 \mathrm{bc}$ & $694.98 \mathrm{a}$ & $625.24 \mathrm{a}$ \\
\hline \multirow[t]{3}{*}{ Sweet Charlie } & Un -mulched & $18.38 \mathrm{c}$ & $18.67 \mathrm{~b}$ & $3.39 \mathrm{~cd}$ & $2.51 \mathrm{~cd}$ & $7.46 \mathrm{~d}$ & $6.55 \mathrm{~d}$ & $207.58 \mathrm{c}$ & $279.71 \mathrm{~b}$ \\
\hline & clear mulch & $20.43 \mathrm{c}$ & $20.21 \mathrm{ab}$ & $4.11 \mathrm{abc}$ & $3.45 \mathrm{ab}$ & $10.32 \mathrm{~cd}$ & $12.78 \mathrm{c}$ & $369.12 \mathrm{~b}$ & $601.61 \mathrm{a}$ \\
\hline & Black mulch & $28.14 \mathrm{a}$ & $21.72 \mathrm{a}$ & $4.44 \mathrm{ab}$ & $4.02 \mathrm{a}$ & $19.51 \mathrm{ab}$ & $22.57 \mathrm{a}$ & 715.99 a & $653.66 \mathrm{a}$ \\
\hline
\end{tabular}

Values followed by the same letter(s), within a comparable group of means of any main effect, do not significantly differ, using revised L.S.D test at $0.05 \%$ level.

Table 4. The Interaction effect between cultivar and tunnel on vegetative growth characters of strawberry plants, during the seasons of 2012/2013 and 2013/2014.

\begin{tabular}{|c|c|c|c|c|c|c|c|c|c|}
\hline \multirow[t]{2}{*}{ Cultivar } & \multirow{2}{*}{ Tunnel } & \multicolumn{2}{|c|}{ Number of leaves } & \multicolumn{2}{|c|}{$\begin{array}{l}\text { Number of } \\
\text { crown }\end{array}$} & \multicolumn{2}{|c|}{$\begin{array}{c}\text { Total dry weight } \\
(\mathrm{g} \mathrm{m})\end{array}$} & \multicolumn{2}{|c|}{$\begin{array}{c}\begin{array}{c}\text { Leaf area } \\
\left(\mathrm{cm}^{2}\right)\end{array} \\
\end{array}$} \\
\hline & & $\begin{array}{c}\text { Season } \\
1 \\
\end{array}$ & $\begin{array}{c}\text { Season } \\
2 \\
\end{array}$ & $\begin{array}{c}\text { Season } \\
1\end{array}$ & $\begin{array}{c}\text { Season } \\
2\end{array}$ & $\begin{array}{c}\text { Season } \\
1 \\
\end{array}$ & $\begin{array}{c}\text { Season } \\
2\end{array}$ & $\begin{array}{c}\text { Season } \\
1\end{array}$ & $\begin{array}{c}\text { Season } \\
2\end{array}$ \\
\hline \multirow{2}{*}{ Gafuta } & Non & $18.52 \mathrm{~b}$ & $13.80 \mathrm{~b}$ & $3.63 \mathrm{ab}$ & $2.02 \mathrm{c}$ & $7.04 \mathrm{~d}$ & $6.71 \mathrm{~b}$ & $238.60 \mathrm{~d}$ & $525.23 \mathrm{c}$ \\
\hline & Tunnel & $21.44 \mathrm{a}$ & $16.45 \mathrm{~b}$ & $3.138 \mathrm{~b}$ & $3.66 \mathrm{ab}$ & $6.48 \mathrm{~d}$ & $6.17 \mathrm{~b}$ & $236.39 \mathrm{~d}$ & $220.66 \mathrm{~d}$ \\
\hline \multirow{2}{*}{ Festival } & Non & $25.19 \mathrm{a}$ & $19.99 \mathrm{~b}$ & $3.29 \mathrm{~b}$ & $2.83 \mathrm{bc}$ & $19.35 \mathrm{a}$ & $14.42 \mathrm{a}$ & $575.42 b$ & $595.40 \mathrm{~b}$ \\
\hline & Tunnel & $26.33 \mathrm{a}$ & $23.61 \mathrm{a}$ & $3.71 \mathrm{ab}$ & $4.16 \mathrm{a}$ & $17.17 \mathrm{ab}$ & $16.14 \mathrm{a}$ & $705.83 \mathrm{a}$ & $648.03 \mathrm{a}$ \\
\hline \multirow{2}{*}{ Sweet Charlie } & Non & $21.62 \mathrm{a}$ & $18.22 \mathrm{~b}$ & $3.70 \mathrm{ab}$ & $2.78 \mathrm{bc}$ & $13.65 \mathrm{bc}$ & $13.04 \mathrm{a}$ & $418.84 \mathrm{c}$ & $501.35 \mathrm{c}$ \\
\hline & Tunnel & $23.01 \mathrm{a}$ & $22.19 \mathrm{a}$ & $4.26 \mathrm{a}$ & $3.87 \mathrm{a}$ & $11.23 \mathrm{~cd}$ & $14.89 \mathrm{a}$ & $442.95 \mathrm{c}$ & $521.96 \mathrm{c}$ \\
\hline
\end{tabular}

Values followed by the same letter(s), within a comparable group of means of any main effect, do not significantly differ, using revised L.S.D test at $0.05 \%$ level. 
Table 5. The Interaction effect between mulch and tunnel on the vegetative growth characters of strawberry plants, during the seasons of 2012/2013 and 2013/2014.

\begin{tabular}{|c|c|c|c|c|c|c|c|c|c|}
\hline \multirow{2}{*}{ Mulch } & \multirow{2}{*}{ Tunnel } & \multicolumn{2}{|c|}{ Number of leaves } & \multicolumn{2}{|c|}{ Number of crown } & \multicolumn{2}{|c|}{$\begin{array}{c}\text { Total dry weight } \\
\text { (g m) }\end{array}$} & \multicolumn{2}{|c|}{$\begin{array}{c}\text { Leaf area } \\
\left(\mathrm{cm}^{2}\right)\end{array}$} \\
\hline & & $\begin{array}{c}\text { Season } \\
1 \\
\end{array}$ & $\begin{array}{c}\text { Season } \\
2 \\
\end{array}$ & $\begin{array}{c}\text { Season } \\
1 \\
\end{array}$ & $\begin{array}{c}\text { Season } \\
2 \\
\end{array}$ & $\begin{array}{c}\text { Season } \\
1 \\
\end{array}$ & $\begin{array}{c}\text { Season } \\
2 \\
\end{array}$ & $\begin{array}{c}\text { Season } \\
1 \\
\end{array}$ & $\begin{array}{c}\text { Season } \\
2 \\
\end{array}$ \\
\hline \multirow{2}{*}{ Un mulch } & Non & $18.21 \mathrm{~b}$ & $15.35 \mathrm{c}$ & $2.41 \mathrm{c}$ & $2.14 \mathrm{~b}$ & $10.34 \mathrm{bc}$ & $8.00 \mathrm{c}$ & $332.11 \mathrm{~d}$ & $308.67 \mathrm{~d}$ \\
\hline & Tunnel & $20.77 b$ & $18.89 \mathrm{~b}$ & $3.05 \mathrm{bc}$ & $2.52 \mathrm{~b}$ & $7.96 \mathrm{c}$ & $8.37 \mathrm{c}$ & $355.39 \mathrm{~d}$ & $381.79 \mathrm{c}$ \\
\hline \multirow{2}{*}{ Clear mulch } & Non & $20.54 \mathrm{~b}$ & $17.47 \mathrm{~b}$ & $3.54 \mathrm{~b}$ & $2.98 \mathrm{~b}$ & $10.37 \mathrm{bc}$ & $11.45 \mathrm{bc}$ & $425.07 \mathrm{c}$ & $461.57 \mathrm{~b}$ \\
\hline & Tunnel & $23.41 \mathrm{a}$ & $21.36 \mathrm{a}$ & $4.17 \mathrm{ab}$ & $4.81 \mathrm{a}$ & $14.98 \mathrm{ab}$ & $14.28 \mathrm{ab}$ & $428.47 \mathrm{c}$ & $475.17 \mathrm{~b}$ \\
\hline \multirow{2}{*}{ Black mulch } & Non & $23.58 \mathrm{a}$ & $18.88 \mathrm{~b}$ & $4.04 \mathrm{ab}$ & $2.52 \mathrm{~b}$ & $14.71 \mathrm{ab}$ & $11.88 \mathrm{~b}$ & $499.80 \mathrm{~b}$ & $451.73 \mathrm{~b}$ \\
\hline & Tunnel & $26.61 \mathrm{a}$ & $21.98 \mathrm{a}$ & $4.51 \mathrm{a}$ & $4.36 \mathrm{a}$ & $16.54 \mathrm{a}$ & $17.37 \mathrm{a}$ & $577.20 \mathrm{a}$ & $533.70 \mathrm{a}$ \\
\hline
\end{tabular}

Values followed by the same letter(s), within a comparable group of means of any main effect, do not significantly differ, using revised L.S.D test at $0.05 \%$ level.

Table 6. Main effect of cultivars, mulch and tunnels on flowering traits of strawberry plants, during the seasons of 2012/2013 and 2013/2014.

\begin{tabular}{|c|c|c|c|c|c|}
\hline \multirow{2}{*}{\multicolumn{2}{|c|}{ Treatment }} & \multicolumn{2}{|c|}{ Earliness of flowering (days) } & \multicolumn{2}{|c|}{ Number of flower Trusses/plant } \\
\hline & & Season1 & Season 2 & Season1 & Season2 \\
\hline \multirow[t]{3}{*}{ Cultivar } & Gafuta & $127.85 \mathrm{a}$ & $128.12 \mathrm{a}$ & $20.54 \mathrm{a}$ & $18.83 \mathrm{~b}$ \\
\hline & Festival & $128.23 \mathrm{a}$ & $127.33 \mathrm{a}$ & $21.02 \mathrm{a}$ & $20.77 \mathrm{~b}$ \\
\hline & et Charlie & $123.30 \mathrm{~b}$ & $170.59 \mathrm{a}$ & $19.83 \mathrm{a}$ & $21.490 \mathrm{a}$ \\
\hline \multirow[t]{3}{*}{ Mulch } & Control & $128.34 \mathrm{a}$ & $174.82 \mathrm{a}$ & $16.01 \mathrm{~b}$ & $17.21 \mathrm{c}$ \\
\hline & Clear & $126.47 \mathrm{~b}$ & $126.57 \mathrm{a}$ & $23.17 \mathrm{a}$ & $20.77 b$ \\
\hline & Black & $124.57 \mathrm{c}$ & $124.56 \mathrm{a}$ & $22.23 \mathrm{a}$ & $23.12 \mathrm{a}$ \\
\hline \multirow[t]{2}{*}{ Tunnel } & Non & $128.82 \mathrm{a}$ & $128.62 \mathrm{a}$ & $20.22 \mathrm{a}$ & $18.84 \mathrm{~b}$ \\
\hline & Tunnel & $124.11 \mathrm{~b}$ & $125.40 \mathrm{a}$ & $20.72 \mathrm{a}$ & $21.89 \mathrm{a}$ \\
\hline
\end{tabular}

Values followed by the same letter(s), within a comparable group of means of any main effect, do not significantly differ, using revised L.S.D test at $0.05 \%$ level.

The interaction effect between type of mulch and cultivar on flowering traits; i.e. earliness of flowering and number of trusses/plant; are presented in Table (7). Strawberry plants cv Sweet Charlie which mulched with black mulches was responsible for causing the earliness of flowering and had positive and significant effect on number of flower trusses $/$ plant $^{-1}$, in both seasons. Similar results were reported by Shiow et al (1998).

Results in Table (8) illustrated the significant interaction effect between the tunnel treatments and the three studied cultivars, on flowering traits, in both seasons. The strawberry plants c.vs Festival and Sweet Charlie which tunneled, generally, flowered earlier and produced higher number of flower trusses/plant, in both seasons. However, Festival without tunnel recorded the highest mean values of days from transplanting to floral initiation, indicating that this cultivar requires the tunnel cover to flower earlier. Similar results were recorded by Sevgican (1984) and Levent and Sozer (2001).

The interaction effect between the mulch type and tunnel treatment on earliness and number of flower trusses are shown in Table (9). The results indicated that were significant differences on the studied flowering traits due to mulch type and tunnel treatments, in both seasons. The highest mean value of both characters, were obtained from strawberry plants mulched with black polyethylene mulch and tunneled, in both seasons. The obtained results are in general accordance with those reported by Levent and Sozer (2001) and Medina et al., (2011).

\section{3- Fruit yield and its components:}

The results presented in Table (10), exhibited significant difference among the three studied strawberry cultivars in terms of yield parameters, in both seasons. Sweet Charlie and Festival cultivars were superior to Gaviota with respect to all yield potential characters. These results, also, indicated that there were significant increase in all studied yield parameters, i.e. early yield, yield/plant, total yield, marketable yield, culls and average fruit yield due to the application of mulch compared to the non-mulched control, in both seasons. Early yield, yield/plant, total yield, and average fruit yield were positively and significantly increased a result of application the two types of mulch compared to the non-mulched control. The only exception was 
noticed with marketable yield, culls; where the differences among the mulch treatments were insignificant, in both seasons.

Black mulch is better than clear one, in respect to yield /plant, marketable yield and total yield. Such positive responses of strawberry yield potential to mulch and tunnel treatments may be due to proper balance of microclimate (moisture and temperature) for strawberry plants, which creates favorable conditions for nutrients uptake, photosynthesis and metabolites translocation. Other possibility was increasing available water and nutrients uptake which ultimately accelerated the rate of vegetative growth and yield. These findings appeared to be in general accordance with those reported by several investigators (Baltt, 1984; Nestby, 1985; Hayness, 1987; Lareau and Lamorre, 1990; Shiow et al., 1998; Ali and Radwan, 2008; Medina et al., 2011 and Qureshi et al., 2012).

Results in Table (11) illustrated the interaction effect between the various types of mulches and the three studied strawberry cultivars on yield and its components which were found significant, in both seasons.

Table7. Interaction effect between cultivar and mulch on flowering traits of strawberry plants, during the seasons of 2012/2013 and 2013/2014.

\begin{tabular}{clcccc}
\hline \multirow{2}{*}{ Cultivar } & \multirow{2}{*}{ Mulch } & \multicolumn{2}{c}{ Earliness of flowering(days) } & \multicolumn{2}{c}{ Number of flower Trusses/plant } \\
\cline { 2 - 6 } & & Season1 & Season2 & Season1 & Season2 \\
\hline \multirow{3}{*}{ Gafuta } & Un- mulched & $130.49 \mathrm{a}$ & $130.39 \mathrm{~b}$ & $17.72 \mathrm{~b}$ & $17.24 \mathrm{~d}$ \\
& Clear mulch & $126.79 \mathrm{c}$ & $126.60 \mathrm{f}$ & $23.32 \mathrm{ab}$ & $20.98 \mathrm{bc}$ \\
& Black mulch & $126.29 \mathrm{~d}$ & $127.36 \mathrm{e}$ & $20.58 \mathrm{ab}$ & $18.28 \mathrm{~cd}$ \\
\hline \multirow{3}{*}{ Festival } & Un- mulched & $129.29 \mathrm{~b}$ & $128.21 \mathrm{~d}$ & $16.64 \mathrm{~b}$ & $18.26 \mathrm{~cd}$ \\
& Clear mulch & $129.22 \mathrm{~b}$ & $128.64 \mathrm{c}$ & $22.21 \mathrm{ab}$ & $19.99 \mathrm{~cd}$ \\
& Black mulch & $126.17 \mathrm{~d}$ & $125.15 \mathrm{~g}$ & $24.24 \mathrm{a}$ & $24.07 \mathrm{ab}$ \\
\hline \multirow{3}{*}{ Sweet Charlie } & Un- mulched & $125.26 \mathrm{e}$ & $133.87 \mathrm{a}$ & $13.66 \mathrm{~b}$ & $16.13 \mathrm{~d}$ \\
& Clear mulch & $123.39 \mathrm{f}$ & $124.46 \mathrm{~h}$ & $24.00 \mathrm{a}$ & $21.348 \mathrm{bc}$ \\
& Black mulch & $121.24 \mathrm{~g}$ & $121.44 \mathrm{i}$ & $21.88 \mathrm{ab}$ & $26.99 \mathrm{a}$ \\
\hline
\end{tabular}

Values followed by the same letter(s), within a comparable group of means of any main effect, do not significantly differ, using revised L.S.D test at $0.05 \%$ level.

Table 8. Interaction effects between cultivar and tunnel on flowering traits of strawberry plants, during the seasons of 2012/2013 and 2013/2014.

\begin{tabular}{cccccc}
\hline \multirow{2}{*}{ Cultivar } & \multirow{2}{*}{ Tunnels } & \multicolumn{2}{c}{ Earliness of flowering(days) } & \multicolumn{2}{c}{ Number of flower Trusses/plant } \\
\cline { 3 - 6 } & & Season1 & Season2 & Season1 & Season2 \\
\hline \multirow{2}{*}{ Gafuta } & Non & $129.89 \mathrm{~b}$ & $130.02 \mathrm{a}$ & $21.11 \mathrm{ab}$ & $17.29 \mathrm{c}$ \\
& Tunnel & $125.82 \mathrm{c}$ & $126.22 \mathrm{a}$ & $19.96 \mathrm{ab}$ & $20.38 \mathrm{ab}$ \\
\hline \multirow{2}{*}{ Festival } & Non & $130.82 \mathrm{a}$ & $130.00 \mathrm{a}$ & $18.71 \mathrm{~b}$ & $18.96 \mathrm{bc}$ \\
& Tunnel & $125.64 \mathrm{~d}$ & $124.67 \mathrm{a}$ & $23.34 \mathrm{a}$ & $22.59 \mathrm{a}$ \\
\hline \multirow{2}{*}{ Sweet Charlie } & Non & $125.76 \mathrm{c}$ & $125.85 \mathrm{a}$ & $18.86 \mathrm{~b}$ & $19.28 \mathrm{~b}$ \\
& Tunnel & $120.83 \mathrm{e}$ & $115.33 \mathrm{a}$ & $20.83 \mathrm{ab}$ & $22.71 \mathrm{a}$ \\
\hline
\end{tabular}

Values followed by the same letter(s), within a comparable group of means of any main effect, do not significantly differ, using revised L.S.D test at $0.05 \%$ level.

Table 9. Interaction between mulch and tunnel on flowering traits of strawberry plants, during the seasons of 2012/2013 and 2013/2014.

\begin{tabular}{cccccc}
\hline \multirow{2}{*}{ Mulch } & \multirow{2}{*}{ Tunnels } & \multicolumn{2}{c}{ Earliness of flowering (days) } & \multicolumn{2}{c}{ Number of flower Trusses/plant } \\
\cline { 3 - 6 } & & Season1 & Season2 & Season1 & Season2 \\
\hline \multirow{2}{*}{ Un mulched } & Non & $130.33 \mathrm{a}$ & $129.35 \mathrm{~b}$ & $14.13 \mathrm{~b}$ & $15.69 \mathrm{c}$ \\
& Tunnel & $126.36 \mathrm{~d}$ & $130.30 \mathrm{a}$ & $17.88 \mathrm{~b}$ & $18.73 \mathrm{~b}$ \\
\hline \multirow{2}{*}{ Clear mulch } & Non & $128.88 \mathrm{~b}$ & $129.37 \mathrm{~b}$ & $20.20 \mathrm{~b}$ & $20.21 \mathrm{~b}$ \\
& Tunnel & $124.06 \mathrm{e}$ & $123.77 \mathrm{~d}$ & $25.14 \mathrm{a}$ & $22.336 \mathrm{a}$ \\
\hline \multirow{2}{*}{ Black mulch } & Non & $127.26 \mathrm{c}$ & $127.15 \mathrm{c}$ & $20.38 \mathrm{~b}$ & $20.637 \mathrm{~b}$ \\
& Tunnel & $121.88 \mathrm{f}$ & $122.15 \mathrm{e}$ & $23.08 \mathrm{a}$ & $25.61 \mathrm{a}$ \\
\hline
\end{tabular}

Values followed by the same letter(s), within a comparable group of means of any main effect, do not significantly differ, using revised L.S.D test at $0.05 \%$ level. 


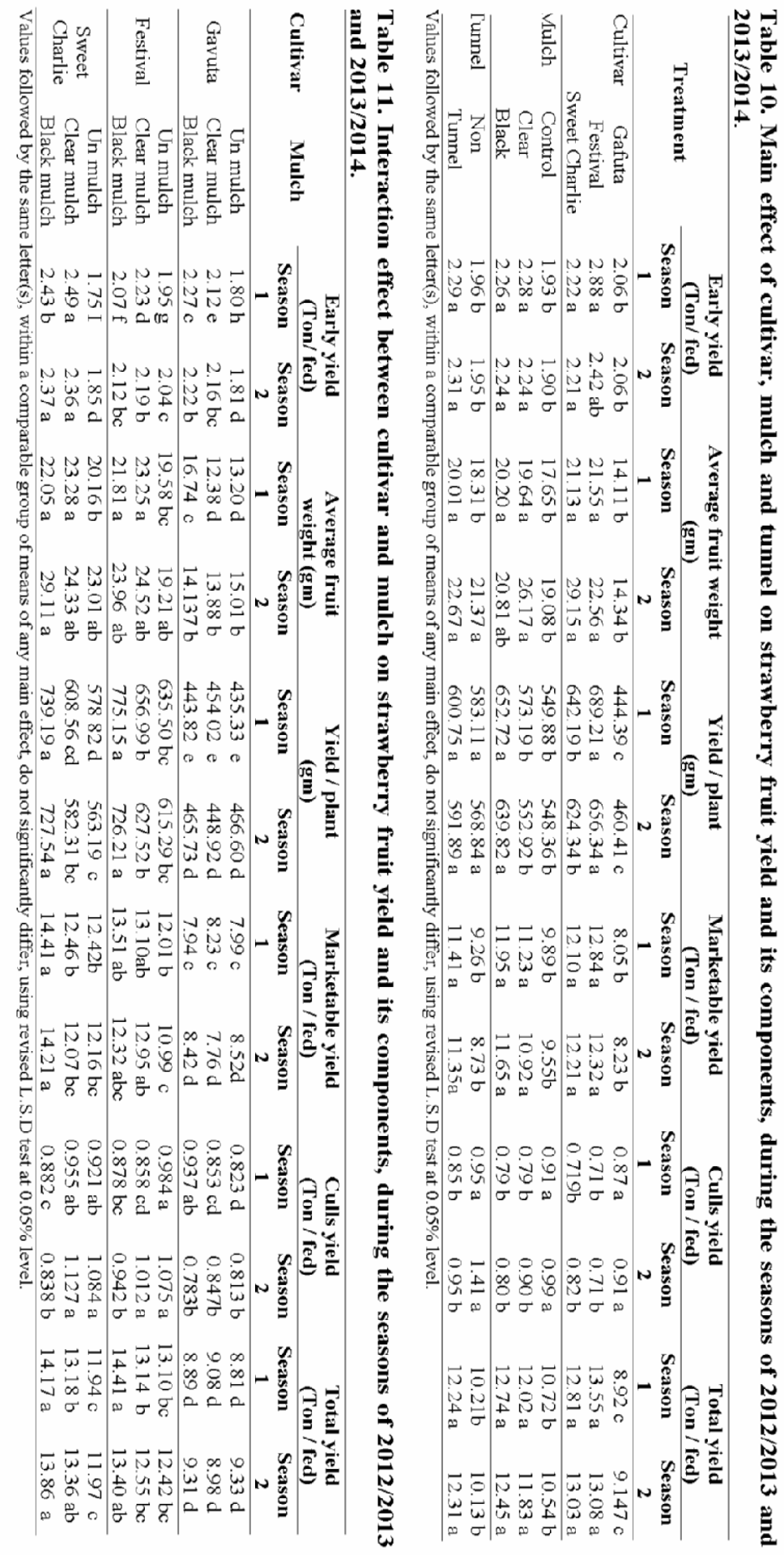




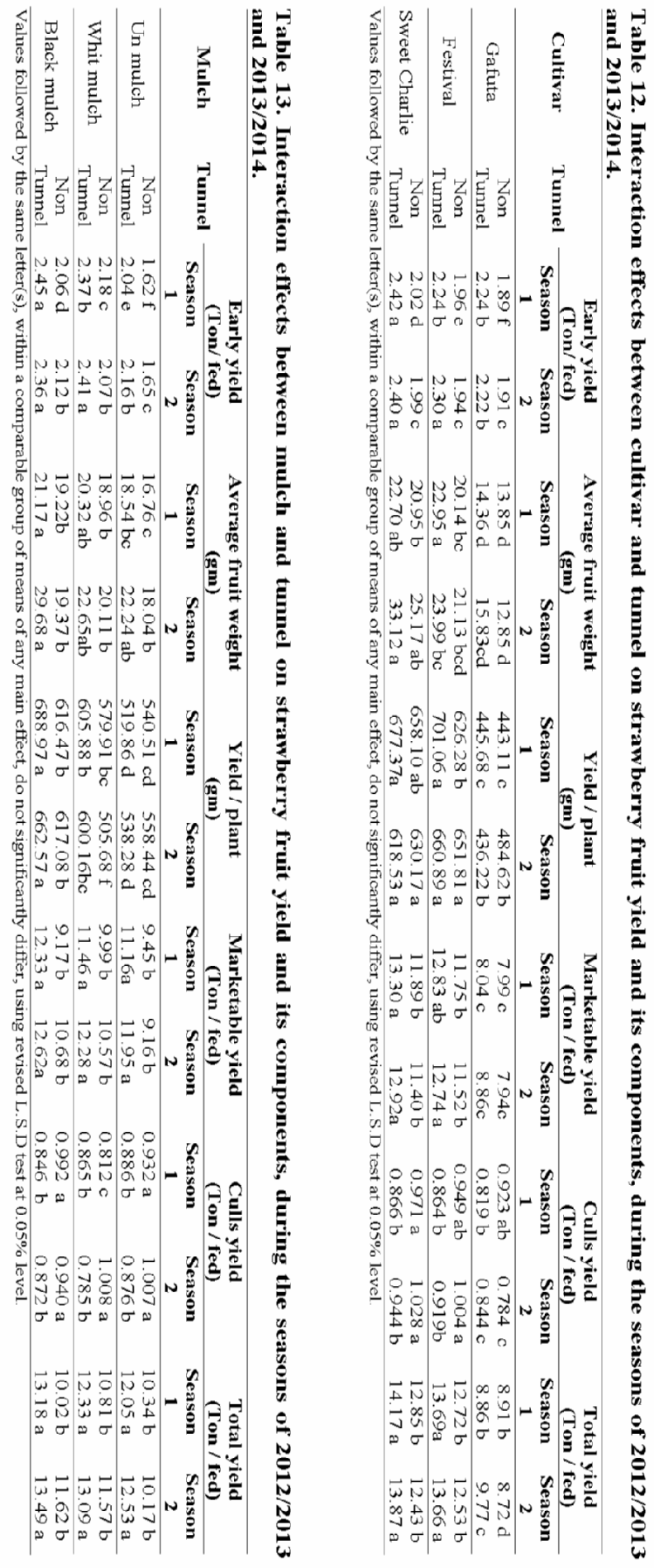




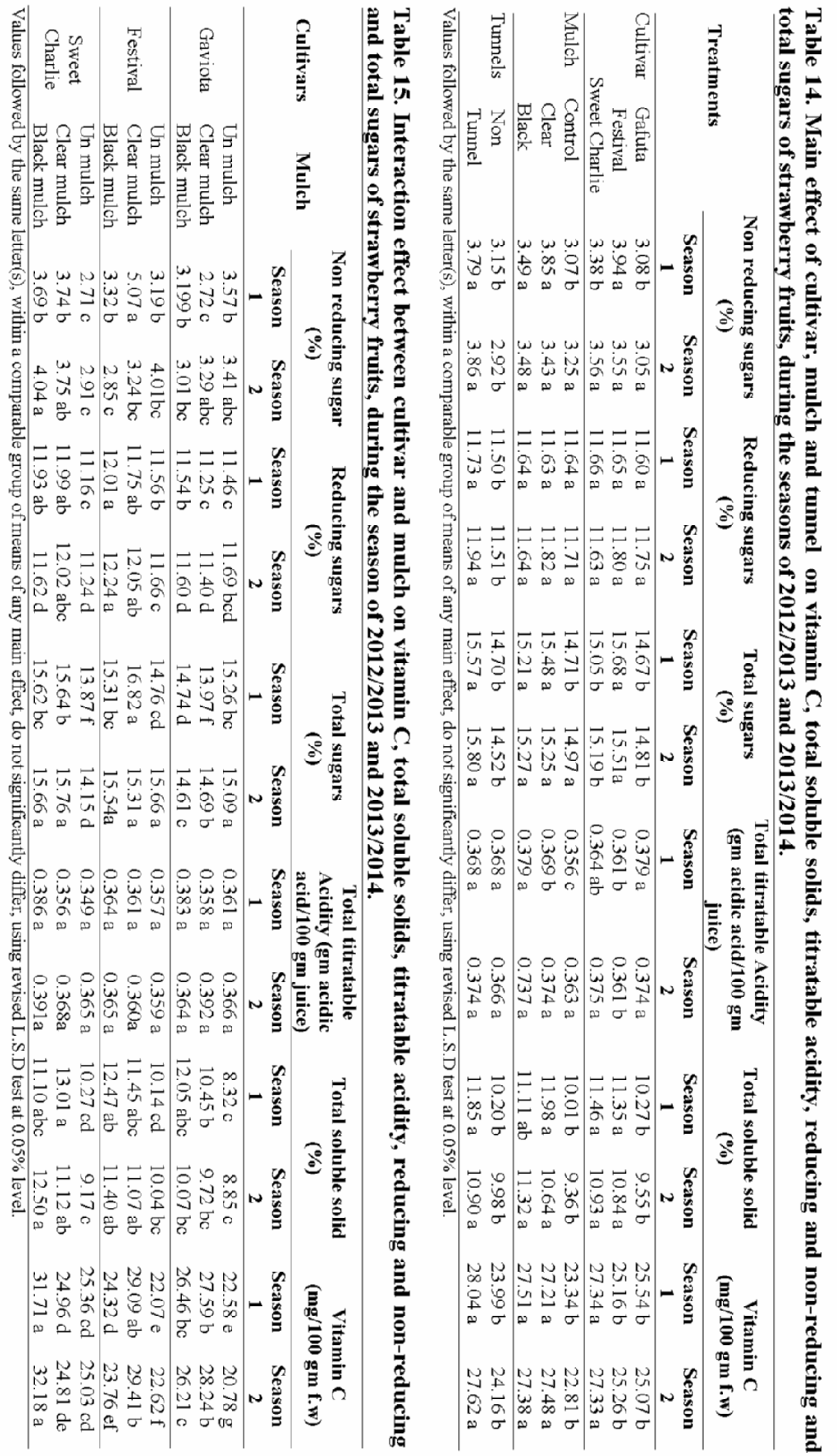




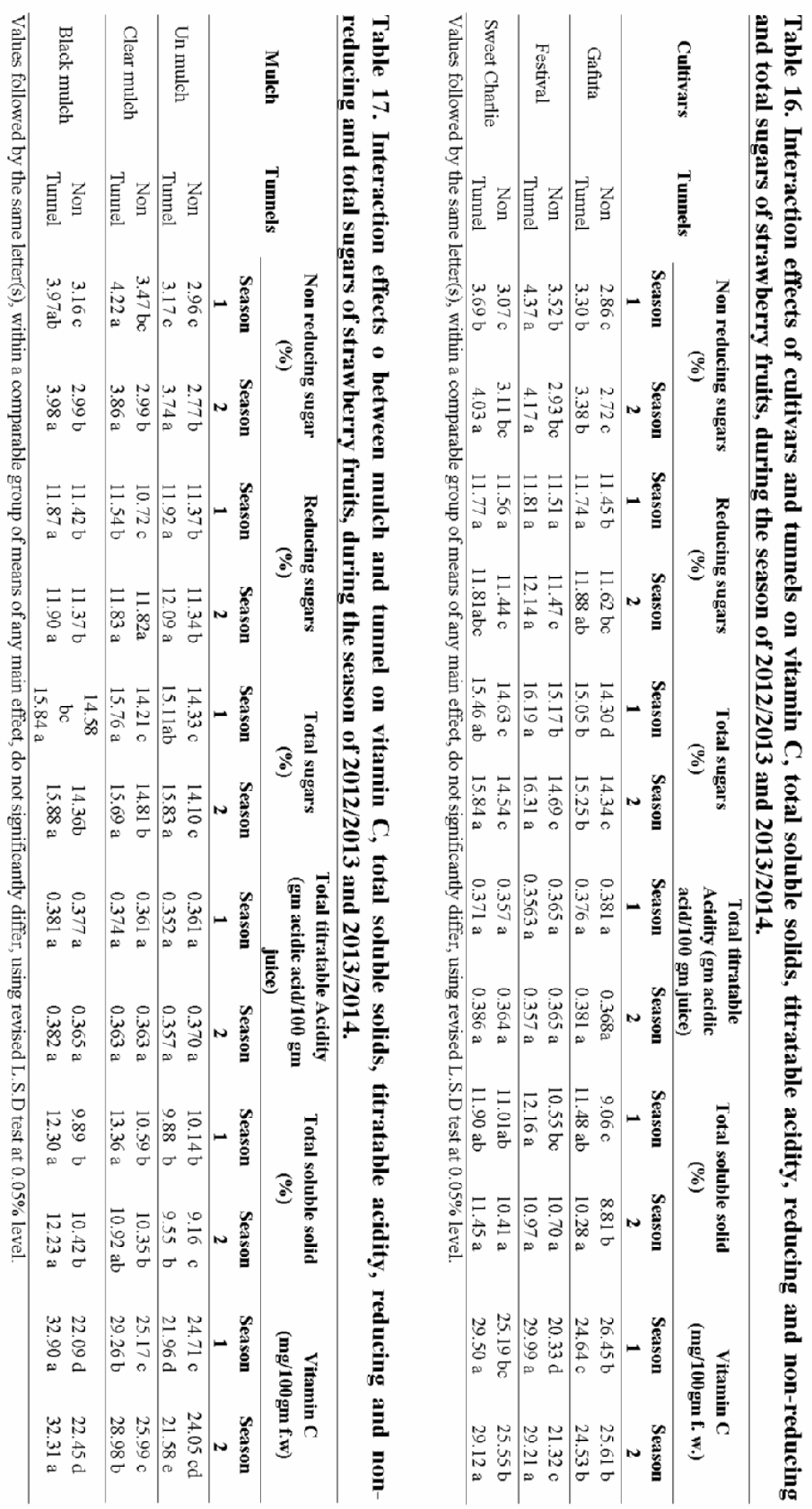


The Sweet Charlie c.v which mulched with black polyethylene and tunneled, generally, produced the highest significant mean values for fruit yield and its components, in both seasons. The obtained results are in general accordance with those reported by (Albregts et al., 1993; Shiow et al., 1998; Ali and Radwan, 2008 and Qureshi et al., 2012).

The difference between tunnel and cultivar were found significant for yield characters and its components (Table 12). The highest mean values for most fruit yield parameters were obtained when strawberry c.vs Festival or Sweet Charlie grown under tunnel than the un-tunneled control one, in both seasons. Similar results were reported by Shiow et al., (1998); Levent and Sozer, (2001) and Qureshi et al. (2012).

The highest mean values of fruit yield parameters (i.e. early yield, yield/plant, total yield, marketable yield, culls yield and average fruit weight) were resulted from the interaction between the mulched and tunneled found significant for yield fruit parameter, Table (13). The strawberry plants were mulched and tunneled gave, in both seasons. Similar results were reported by (Levent and Sozer, 2001).

\section{Fruit quality traits:}

The results in Table (14), generally showed the presence of some significant differences on vitamin $\mathrm{C}$, total soluble solids, titratable acidity, reducing and nonreducing and total sugars, as a result of mulch types and tunnels, in both growing season. Mulch types and tunnels, significantly, improved all fruit quality character, in both seasons. The obtained results, generally, showed significant differences among strawberry plants cv. Festival, Sweet Charlie and Gaviota, in both season. It was observed that, Festival or Sweet Charlie cultivars contained more total soluble solids, V.C and reducing and non-reducing and total sugars than Gaviota one, in both season. However, gaviota fruits had more total titratable acidity than Festival and Sweet Charlie ones. Generally the obtained results compatible with those reported by (Lareau and Lamarre, 1990; Shiow et al., 1998 and Qureshi et al., 2012).

The interaction effects among the cultivar and mulch types on V.C, TSS, Reducing and non-reducing and total sugars are shown in Table (15). The comparisons among the means of the various treatment combinations showed the presence of some significant interaction effects on the V.C, TSS, reducing and non-reducing and total sugars, in both seasons. The highest mean values of these characters were obtained from strawberry plant cv. Festival which mulched with black polyethylene.
However, no significant difference in total titratable acidity was detected, in both seasons. The obtained results are in general accordance with those reported by (Shiow et al 1998). The results presented in Table (16), illustrated the interaction effects between cultivars and tunnels of strawberry plant on the total soluble solids, vitamin $\mathrm{c}$, reducing and non-reducing and total sugars were found to be significant, in both season. The best results for these characters were obtained from strawberry cv. Sweet Charlie which grown under tunnel, in both season. However, total titratable acidity were not significantly, affected by these interaction. Similar results were recorded by (Levent and Sozer, 2001; Medina et al., 2011 and Qureshi et al., 2012).

The interaction effects between mulch types and tunnels on V.C, TSS, TTA, reducing and non-reducing and total sugars are presented in Table (17), in both seasons, the strawberry plants which were mulched and tunneled gave the highest mean values for total sugars,

vitamin $\mathrm{C}$, reducing and non-reducing and total sugars compared than control treatment. However, total titrable acidity were not significantly affected. Similar results were recorded by Levent and Sozer, (2001).

\section{CONCLUSIONS}

Based on the results from this study, application of plastic mulch and low tunnel for production strawberry plants caused significant increments in vegetative growth characters, fruit yield and its components and improved fruit quality. Fistival cultivar exhibited the superiority, in this respect.

\section{REFERENCES}

Abu El-Yazied, A and M. A. Mady., (2012). Plastic color and potassium foliar application affect growth and productivity of strawberry (fragaria $\times$ annanassa Dush). Juarnal of applied Science Research. 8(2): 1227-1239.

Aguyoh J; Taber H.G and Lawson V., (1999). Maturity of fresh market sweet corn with directseeded plants, transplants, clear plastic mulch and rowcover combinations. Hort Technology. 9 (3): 420-425.

Al Bregts, E. E and C. k. Chandler., (1993). Effect of polyethylene mulch color on fruit response of strawberry. proc. Soil Crop Sci. Florida. 52: 40-43.

Ali, R.A.M. and E.A. Radwan., (2008). Effect of organic and synthetic mulches of some fresh strawberry cultivers, J. Agric. Env. Sci. Alex. Univ., Egypt.

Anttonen, M. J, Hoppula, K. L; Nestby, R; Verheul, M. J and Karjalainen, R. O., (2006). Influence of fertilization, mulch color, early forcing, fruit order, planting date, shading, growing environment and genotype on the contents of selected phenolics in strawberry production. Journal of plant Nutrition 29: 103-112. 
Black, C. A., (1965). Methods of soil analysis Amer. Soc. of Agron. Madison, Wisconsin, USA.

Blatt, C. A., (1984). Irrigation, mulch and double row planting related to fruit size and yield of Bounty strawberry. Hort. Sci. 19 (6): 826-827.

Bultin of the Agricultural Statistics Winter Crop Part (1) Ministry of Agriculture 1992.

El- Shall, M. A; S. M. El-Araby, I. M. Ghoneim and H. Anter., (2003). Effect of biofertilization under varying NPK levels on growth yield and fruit quality of strawberry plants. J. Agric. Env. Sci. Alex. Univ., Egypt, 2: 106-129.

Faspi, F; Salmeron, A; Fontecha , A; Gareta, Y and Real, A., (2006). Plastic film for agricultural applications. J. Plastic Film $\neq$ Sheeting 22: 85-101.

Fear, C. D and G. R. Nonnecke., (1989). Soil mulches influence reproductive and vegetative growth of Fern and Tristar day natural strawberries. HortScience. 19 (6): 826827.

Gimenez. C; R. F. Otto and N. Castilla., (2002). Productivity of leaf and root vegetable crops under direct cover. Sci. Hort. 94: 1-11.

Halvorsen; B. L, K. Holte; M. C. W. Myhestad; J. Bayikmo; E. Hvatium; S. F. Remberg; A. B. Wold; K. Haffner; H. Buugered; L. F. Andersen; J. G. Moskauy; D. R. Jacobs; JR and R. Biomhoff., (2002). Asystematic screening of total antioxidents in dietary plants. J. Nutr. 132, 461-471.

Hasanein, N. M; Manal, M. H. Gad El-Mola and Mona, A. M. Aly., (2011). Influence of different color of shade on growth and Yield of strawberries and different color of plastic Mulch under low tunnels conditions. Res. J. Agric S Biot. Sci. 7 (6): 483-490.

Haynes, R., (1987). The use of polyethylene mulches to change soil microclimate as revealed by enzyme activity and biomass nitrogen, sulphar and phosphorus. Biology and Fertility of soils. 5 (3): 235-240.

Himelrick. D. G., (1982). Effect of polyethylene mulch color on soil temperature and strawberry plant response. Adv. Strawberry Prod. 1: 15-16.

Kadir, S; Carey, E and Ennaahli, S., (2006). Influence of high tunnel and field conditions on strawberry growth and development. Hort. Sci. 41: 4581-4589.

Kallio; H. M. Hakela; A. M. Pelkkikangas and A. Lapveleianen., (2000). Sugars and acids of strawberry varieties. Europ. Food Res. Tech. 212. 81-85.

Khanizadeh, S., (1994). Breeding strawberries for Eastern central Canada. Euphytica 77:45-49.

Kher R; Baba J. A and Bakshi P., (2010). Influence of planting time and mulching material on (4): 441-444.

Kivijarvi, P; Parikka, P and Tuovinen, T., (2002). The effect mulches on yield, fruit quality and strawberry mite in organically grown strawberry organic production of fruit and berries. The Danish Inst. of Agric. Sci. Dep. of Hort. Arslev, Denmark.
Lareau, M. J and Lamarra., (1990) .Effects of row cover and mulching in the producti on of day neutral strawberry cultivers . In the strawberry into the 21 st century. Proc. of the third North Amer. strawberry conf. Houston. c. a. Hort. Abst. 63(5). 1993).

Levent Arin and Sozer Ankara., (2001). Effect of low-tunnel, mulch pruning on the yield and earliness of tomato in unheated glasshouse. J. Appl. Hort., 3(1): 23-27.

Li Fan; Valentine Roux, Claudine Dube; Denis Charlebois; Shutiantao, and Shahrokh Khanizadeh., (2012). Effect of mulching systems on fruit quality and phytochemical composition of newly developed strawberry lines. Agric. and Food Sci. 21: 132-140.

Lieten, F and Beats., (1991). Research on strawberries. No Future for coloured film. Onderzock. Qardbet Geen toekomst voor gek-leurde folies. Groenteno fruit. vollegronds groenten. 1 (29): 10-11. (c. a. Hort. Abst. Vol. 62, No. 8. 1992).

Medina, Y; A. Gosselins; R. Harnois; L. Gauthier; S. Khanizadeh (2011). Effect of plastic mulching on yield and fruit quality of strawberry plants grown under high tunnels. Acta. Hort. 893.

Muhammad Haroon; Mohammed saeed; Ijaz Ahmed; Rahamdad Khan; Shahida Bibi; Saeedullah Khattak and Hidayatullah., (2014). Weed density and strawberry yield as affected by herbicides and mulching techniques. Pak. J. Weed Sci. Res., 20(1): 67-75.

Nestby, R., (1985). Mulching of strawberries with clear polyethylene and control of weeds under the mulch. Jorddekking medklar plasti Jodbear, og ugraskontrall under plasten. forskning og forsake landbruket. 36 (3): 103-107.

Orzolek, M. D. and Murphy, J. H., (1993). The effect colored polyethylene mulch on the yield of squash and pepper. Proc. Nat. Agri. Plastics Cong. 24: 157-161.

Osiru, T. and Hahn J., (1994). Effects of mulching on the growth yield and quality of yams. J. Plant Physiology. 64 (8): 201-205.

Pan, H.Y. K.J. Fisher and M.A. Nichols., (1999). The effect of mulch and row covers on yield of process tomatoes. Acta. Hort. 487: 145-150.

Qureshi; S. Chughtai; A. Saleom, (2012). Impact of cultivation system on growth and yield of strawberry (Fragaria $\times$ ananassa) c.v. chandler. Pakistan. J. Agric. Res. vol 25 No. 2-2012.

Salman. S.R., A.E. Abou-Hadid., A.S. El-Beltagy and T.T. Ellabban, (1991). The interaction between plastic mulch and irrigation. Egy. J. of Hort. Pupl. 18(1): 77-86.

Sevgican, A. (1984). Alack plastik tuneller. Egc. Univ. Zir. Fak. Dergest, 21 (1): 101-104.

Shiow, Y. W., G. T. Galletta and M. J. Comp, (1998). Mulches types effect fruit quality and composition of tow strawberry genotypes . Hort . Sci . 33 (4): 636 - 640. 
Teasdale, J. K and A. A. Abdul-Baki., (1995). Soil temperature and tomato growth associated with black polyethylene and hairy vetch mulches. J. A. Soc. Hort. Sci. 120: 848-853.
Teasdale, J. K and A. A. Abdul-Baki, (1997). Growth analysis of tomato in black polyethylene and hairy vetch production system. Hort. Sci. 32 (4): 659-663

Wang, S. Y; Zheng, W and Galleta, G. J, (2002). Cultural system affects fruit quality and antioxidant capacity in strawberries. J. Agri. Food Chem. 50: 6534-6542.

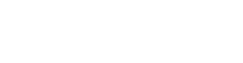

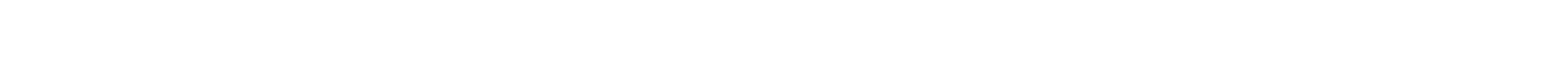

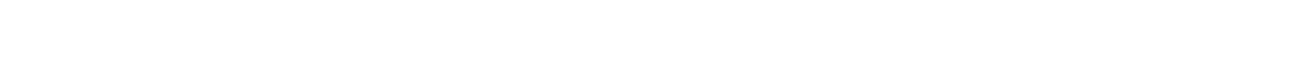

والتبكير فى الازهار وذلك مقارنة بالكتنرول(بدون ملش -

عنم وجود اغطية بلمنتيكية).

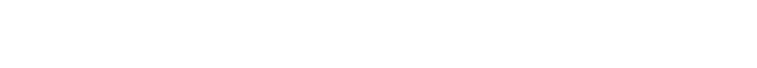

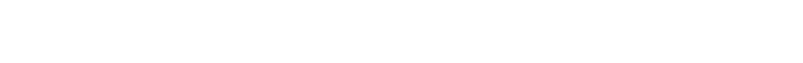

معبرأ عنها بالمحصول المبكر والمحصول الكلى ومحصول

النبلت الولحد والمحصول الصالح للتسويق والمحصول

التاف وكذلك متوبط وزن الثمرة وذك مقارنة بالكنترول.

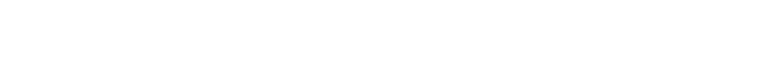

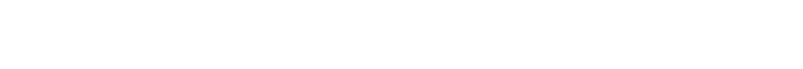

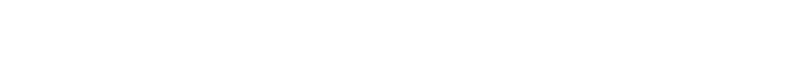
والمختزلة وغير المختزلة وذلك مقارنة بالكنترول.

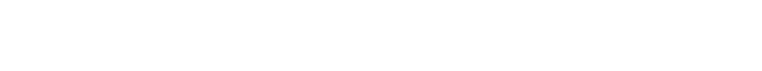

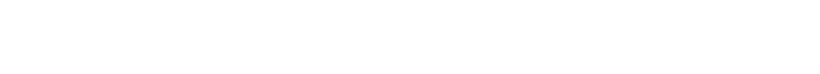
شارله على الصف جافيوتا.
لجريت درلسة حقليه خلال الموسم الصيف لعلم

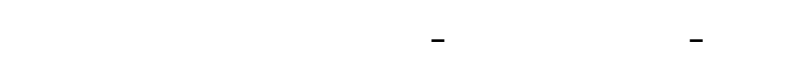

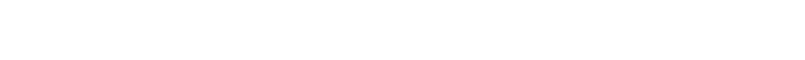
البساتين والكائنة بمحلظة البحيرة. وذلك بهرف دريلسة

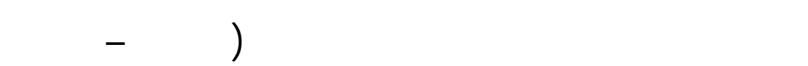
شارله- جافيوتا) لثلاثة معلملات من الملث الصناعى (البوله اليثيلن الابيض. البوله اليثيلين المسود. والكنترول)

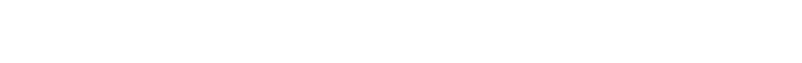
هذه الاففق والفاعل بينهما على النمو الخضرى والإزهار والمحصول وجودة ثمار الفراولة. أوضضت النتائج أن معلملة أصنف الفراولة بأنواع

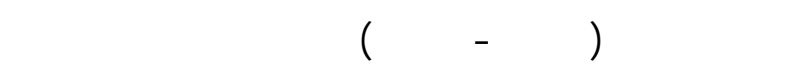

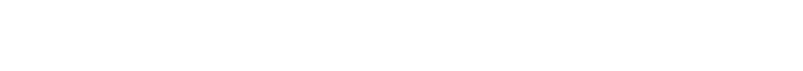

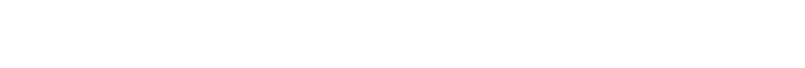
الورقية والوزن الجف وعدد النورات الزهريه للنبات 